ppi $201502 Z U 4645$

Esta publicación científica en formato digital es continuidad de la revista impresa ISSN-Versión Impresa 0798-1406 / ISSN-Versión on line 2542-3185Depósito legal pp $197402 Z$ U34
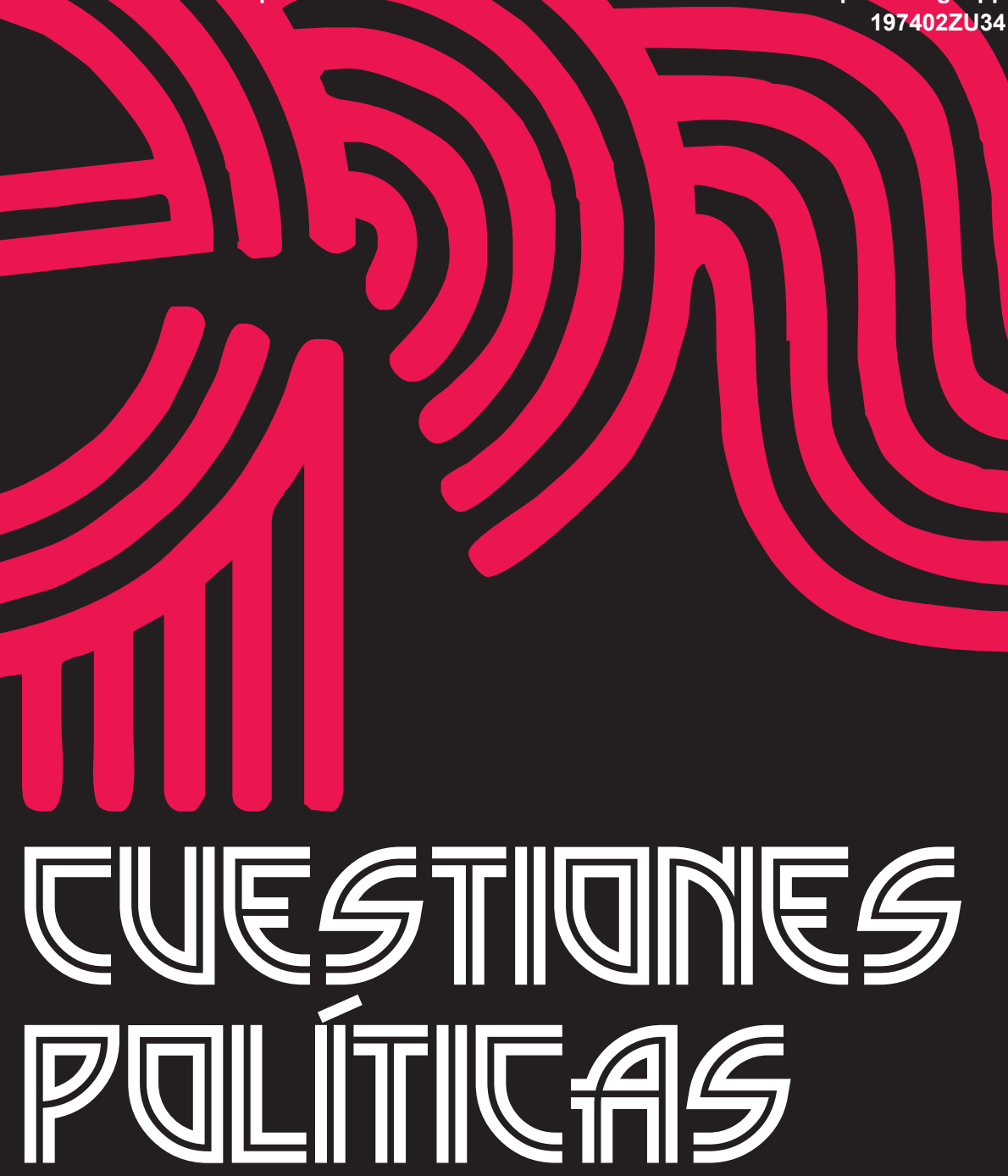

Instituto de Estudios Políticos y Derecho Público "Dr. Humberto J. La Roche" de la Facultad de Ciencias Jurídicas y Políticas de la Universidad del Zulia Maracaibo, Venezuela
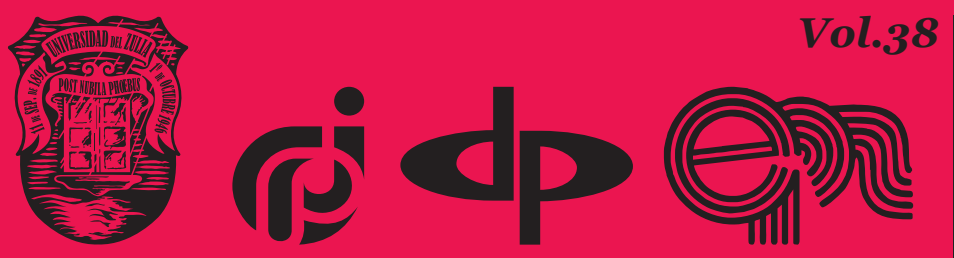

$N^{\circ}$ Especial 2da Parte 2020 


\title{
Distance and Online Learning Solutions in the Context of Modern Legal Educational Policy
}

\author{
DOI: https://doi.org/10.46398/cuestpol.382e.18
}

\begin{abstract}
Raviya Faritovna Stepanenko * Irina Nailjevna Ainoutdinova ** Natalya Viktorovna Krotkova***
\end{abstract}

\section{Abstract}

The objective of this article is the best strategies and models of distance and online education to universities in the context of modern legal education policy, tempting its effectiveness. The methodological framework of this research is based on the comparative anective of distance and online education best practices offered by some universities around the world. A full study of the technical, pedagogical and managements issus of distance education has also been provided. Based on an empirical approach, testing, evaluation and control of usability, accessibility, file and security of some techniques, and related resources have been carried out. An experimental study has also been conducted with the aim of obtaining, comparing and using certain relevant data on the attitudes, priorities and learning outcomes of law students in a traditional versus distance learning environment. The main result of the study is the design of a model of mass, open and lively distance learning and teaching that enhances the quality of university education in general and the training of law students in particular.

Keywords: law students; legal education policy; distance learning and online; COVID-19 pandemic; learning solutions.

\footnotetext{
* Kazan Federal University (Russian Federation), Doctor of jurisprudence, Associate Professor; Professor of the Department of Theory and History of State and Law, Faculty of Law, ORCID ID: https://orcid. org/oooo-0oo2-4748-9195. Email: Stepanenkorf@yandex.ru

** Kazan Federal University (Russian Federation), Doctor of Pedagogical Sciences; Associate Professor; Professor of the Department of foreign languages, Institute of International Relations. ORCID ID: https://orcid.org/oooo-0002-9162-7604. Email: iainoutd@mail.ru

*** Institute of State and Law RAS (Russian Federation), PhD in Law, Candidate of jurisprudence, Associate Professor, the Leading Researcher of Sector of Constitutional Law and Constitutional Justice of the Institute of State and Law of the Russian Academy of Sciences, Moscow, Russia. ORCID ID: https://orcid.org/oooo-0003-2853-128. Email: krotkova2012@yandex.ru
} 
Raviya Faritovna Stepanenko, Irina Nailjevna Ainoutdinova y Natalya Viktorovna Krotkova
240 Distance and Online Learning Solutions in the Context of Modern Legal Educational Policy

\section{Soluciones de aprendizaje a distancia y en línea en el contexto de la política educativa jurídica moderna}

\section{Resumen}

El objetivo de este artículo es analizar las mejores estrategias y modelos de educación a distancia y en línea aplicables a las universidades rusas en el contexto de la política educativa legal moderna, considerando su efectividad. El marco metodológico de esta investigación se basa en el análisis comparativo de las mejores prácticas de educación a distancia y en línea que ofrecen algunas universidades del mundo. También se ha proporcionado un estudio completo de las cuestiones técnicas, pedagógicas y de gestión de la educación a distancia. Con base en un enfoque empírico, se han realizado pruebas, evaluación y control de usabilidad, accesibilidad, disponibilidad y seguridad de algunas técnicas, herramientas y recursos relacionados. También se ha realizado un estudio experimental con el objetivo de obtener, comparar y emplear ciertos datos relevantes sobre las actitudes, prioridades y resultados del aprendizaje de los estudiantes de derecho en un entorno de aprendizaje tradicional versus a distancia. El principal resultado del estudio es el diseño de un modelo de enseñanza y aprendizaje a distancia masivo, abierto y vivencial que potencia la calidad de la educación universitaria en general y de la formación de los estudiantes de derecho en particular.

Palabras clave: estudiantes de derecho; política educativa legal; aprendizaje a distancia y en línea; pandemia COVID-19; soluciones de aprendizaje.

\section{Introduction}

Both national legislation on education and the state policy on education depend on many external and internal socio-economic factors and with time tend to undergo tremendous changes. These alterations correlate with various global and internal processes and trends that influence at large the state and society, labor markets and educational institutions. These shifts further contextually impose high burden of requirements on the system of education (Shkatulla, 2007). The information revolution, which began in the last decades of the 2oth century, contributed to the development of the so-called information society, in which the significant part of activities of people began to largely depend on their awareness and ability to effectively receive, extract, process, apply and exchange information using techmediated communication means (Crawford, 1983). 
The rapid growth in telecommunications, availability of the broadband Internet, ubiquitous access to quick and user-friendly gadgets and electronics spawned a public request to completely reform higher education in Russia so as to improve its quality and meet the requirements and needs of the new digitizing world with its innovative global economy, competitive markets and multicultural diversity (Ainoutdinova et al., 2017).

The provisions of the Federal Educational Standards and the Federal Law "On education" No. 273 legitimized distance and e-learning methods and technologies, which expanded the capacity of universities to create and implement their educational programs of different level of complexity with various majors both independently and via digital networks. The project "Modern Digital Educational Environment of the Russian Federation", which is being successfully implemented in our country now involves creation of conditions for improving the quality of education and bringing educational programs of universities into line with the needs of the digital economy. The new cohort of university law students known as Generation $\mathrm{Z}$ also cause their teachers to entirely alter their concepts and methods of teaching and instructing (Ainoutdinova et al., 2017).

The recent spread of the COVID-19 turned to be a strong stress test for education systems throughout the globe though, with an increasing number of countries closing their institutions of learning as a response to the pandemic. In order to keep the doors of learning open there were large-scale efforts on the part of the governments, authorities, educational institutions and all participants of educational process to utilize technology in support of remote modes of teaching and learning. Appropriate organization of distance and online education were the key answers to most of the emerging challenges. No wonder, that education has changed dramatically, with the distinctive rise of e-learning, whereby teaching was undertaken remotely on digital platforms like Microsoft Teams, Zoom, etc (International the news, 2020). In these unprecedented times, many international organizations along with policymakers, university administrators and teachers assisted students with a variety of open educational resources and tools ( $\mathrm{Li}$ and Lalani, 2020).

Although even before COVID-19 there was already a high increase in the interest of some Russian educators and teachers in various electronic forms of teaching and learning, we can assume that COVID-19, oddly enough, gave impetus to the popularization and practical use of distance and online education in Russia. Thus, to ensure the succession and continuity of educational policy and training activities of future lawyers, a wide arsenal of modern teaching/ learning materials and Internet resources was used at Kazan University. In particular, during the period of quarantine or "selfisolation" law students continued their full-fledged training, but in a remote format. This happened both in synchronous mode (through online training 
with a mandatory Internet connection on the Teams and Zoom platforms), and through asynchronous network interaction via LMS Moodle, blogs, chats, forums, electronic resources hosted on external educational sites, etc. This made it possible to implement online learning into the educational process and make it an integral part.

At the same time, many contradictions of psychological, pedagogical, methodological and technological nature were revealed that require deep analysis and study. With this sudden and forced transition to remote mode of learning, most educators and teachers are wondering whether distance and online learning will continue to persist in post-pandemic conditions, and how such a shift would affect the educational market, educational services and educational opportunities at large ( $\mathrm{Li}$ and Lalani, 2020). In order to answer the questions we have to analyze the existing experience and practice, identify possible obstacles and find solutions for the effective implementation of distance and online learning into the curricula for training future lawyers after the COVID-19 pandemic. This approach supports the demand of the Russian society for the training of highly qualified legal personnel for the digital economy, and also meets the expectations and evolving learning styles of modern students related to “digital generation Z" (Villa and Dorsey, 2017).

\section{Methods}

The methodological framework of this research work rests on a set of social, pedagogical, integrative, competence and comparative approaches covering all aspects of both teachers' and students' academic activities enhanced by the needs and challenges of the digital era (Shkatulla, 2007; Ainoutdinova etal., 2017). A comprehensive analysis of technical, pedagogical, and managerial issues of distance education as an efficient online form of study at university has been provided (Ainoutdinova et al., 2019). The need to study the best international practices of distance and online learning has been caused by the aim to analyze and identify the applicable modes and models capable to serve as a source of innovation and reform of university education in Russia including law students` training.

Our study has been supported by deep analysis and synthesis of the best scientific findings on the topic presented by the prominent Western and Asian scholars (K. Aoki, D. Keegan, F.B. King, L.C. Ragan, N. Sampson, M. Warschauer, etc.) (Aoki, 2010; Keegan, 1996; King et al., 2001; Ragan, 2012; Sampson, 2003; Warschauer, 2007).

Based on the empirical approach testing, evaluation and control of usability, accessibility, availability and safety of some digital distance and 
online learning technologies, methods, techniques, tools and resources have also been performed. An experimental study has also been conducted to obtain and compare certain relevant data concerning the learning outcomes of university students in a traditional versus online (distance) learning environment.

The process involved more than 300 law students who were temporarily placed into separate learning environments, i.e. conventional or traditional (face-to-face) and online (at a distance). We took into account the latest US national research statistics and findings on Generation $\mathrm{Z}$ published by the Center for Generational Kinetics based in Austin (Texas, USA) (Villa and Dorsey, 2017). First, we analyzed the general and most defining characteristics of the Gen Z students; and then their preferred learning styles and modes. In the end, we examined with due diligence the applicable teaching and learning methods and techniques, which will simultaneously address academic and social skills of Gen $\mathrm{Z}$ law students as well as support their "digital" learning expectations and needs.

We also interviewed law teachers working at Kazan University in order to identify their attitudes and readiness to online teaching. The total number of teachers surveyed was more than 30, aged from 25 to 60 years. The survey was conducted by distributing individual questionnaires issued to each participant. The event was held after the teachers ` working hours, all of them having been previously instructed on the rules and goals of the survey. Participation in the study was voluntary and confidential. This survey does not pretend to show any in-deep scientific data; rather, it was an attempt to collect primary information to confirm our hypotheses that the higher the teacher's ICT-competency and ICT-literacy are, the better and more effective online training will be as well as the final students learning outcomes.

The data-driven analysis of the survey results showed that participants (32 law teachers) could be divided into three groups as follows: (1) those who fully support integration of online learning into educational settings and possess positive attitudes toward ICT (42\%); (2) those who oppose online forms of teaching and show negative attitudes toward ICT (34\%); (3) those who generally possess positive attitudes towards ICT, use computers and the Internet in everyday life but feel scared when it comes to ICT integration into educational process due to various reasons (24\%). The results also showed that at least four factors - confidence, ICT knowledge (including ICT-competency and literacy), gender and age - should be taken into account when measuring teachers' attitudes toward digital technologies and when grading their readiness to online practices (Kale and Goh, 2014). 
Raviya Faritovna Stepanenko, Irina Nailjevna Ainoutdinova y Natalya Viktorovna Krotkova
244 Distance and Online Learning Solutions in the Context of Modern Legal Educational Policy

\section{Results and Discussion}

The main result of the study is the design and implementation of the model of an efficient and effective student-centered digital learning environment of university that involves distance or online education programs and enhances the quality of education in general and professional (experiential) training of future lawyers in particular.

In ourvision, university environment should bea multilingual educational space based on inclusion of the native language and one or more foreign languages being taught to students (English, German, French, or Spanish). Such space shall functions in the interconnection and complementarities of all its components that are traditionally integrated into educational process of university (Brown \& Lippincott, 2003). The learning environment should also be organized in accordance with the changing learning needs and styles of the "Gen Z" students, their preferences, and capabilities (Villa and Dorsey, 2017).

The learning environment should thus be organized with a due ICTbased or digital support where educational tools and resources might function as adaptive, familiar, and comfortable instrumental facilitators and drivers of the learning process. The digital environment of university, supported by direct quick access to computers and the broadband Internet, should include the well-structured university's website, educational portal for electronic and distance learning offering inter alia access to massive open online courses (MOOCs), information-sharing crowdsourcing communities, networking virtual platforms, digital libraries, etc (Jansen and Van Der Merwe, 2015).

Classrooms and lecture rooms should be equipped with all sorts of digital devices and multimedia equipment, adapted for work with external, remote, and internal free easily accessible digital educational resources (Brown and Lippincott, 2003). Moreover, universities shall not fear to integrate their institutions with the communities in which they exist and operate. Culture of sharing ideas for enhancements in educational context is receiving the increasing support today. The reason is obvious: distance education initiatives give universities better chances to hear from students, faculties and community members about their current advances and drawbacks (Stepanenko et al., 2019). Distance education ideas help universities remain competitive, build their reputation, enroll more students that are new, etc. Besides, being receptive to ideas and change makes universities much more attractive to prospective students.

To clarify the conceptual apparatus and eliminate the evident lack of a precise vocabulary in the field, we analyzed various viewpoints and came to conclusion that meaning of the terms "distance learning", "distance 
education", "e-learning", "online learning", etc. is almost the same and may in some cases be used interchangeably. Given that, all terms imply learning outside the classroom and out of direct contact with teachers or instructors, which requires greater self-discipline and self-sustainability from students, these approaches still have a slight difference.

In short, this difference can be represented as follows. If the concepts of "distance learning" and "distance education" are often associated with education by correspondence and actually indicate only a distance between students and teachers, then both traditional and specific digital or online methods, means and tools based on computers or the Internet (e.g., telecommunication technologies) can equally be used in the learning process (Jansen and Van Der Merwe, 2015). The concepts "online learning" and "e-learning" mean that the process of study of a particular discipline or topic also takes place outside the classroom (at a distance), but only using the Internet connection.

In other words, "online learning" or "e-learning" is the process of acquiring knowledge and skills in the "here and now" mode of study, but with the help of computers or other gadgets connected to the Internet, through which interaction and exchange of information shall take place (Keegan, 1996). Distance education may thus be defined as a mode of teaching and learning characterized by separation of teacher and learner in time and/ or place for most part of training, digitally enhanced delivery of learning content and gradual knowledge acquisition with a possibility of two-way interaction (learner-teacher and learner-learner) as a basis of meaningful communication for better learning outcomes (King et al., 2001).

The data driven analysis proved that most of the students showed better learning outcomes in the digital learning environment strengthened by various distance learning initiatives ( $58 \%$ against $42 \%$ ). Students can benefit greatly from distance or online education in different ways. Based on research provided by Chris Evans and Jing Ping Fan (Evans and Fan, 2002), we admit that there are at least 3 major advantages of distance and online learning, namely, learner-determined location for learning - whereby students are able to choose their own place of study; learner-determined time of learning - students are able to organize their own individual learning schedule, rather than having to study on a specific day at a specific time; and finally, learnerdetermined pace of study - students are able to set their own individual pace of study without being held up by slower students or vice-versa (Evans and Fan, 2002).

Moreover, distance education sends an important and very deep social message: it affords educational opportunities to individuals unable to attend conventional classroom settings no matter what the reason is. Not only those students with disabilities will benefit from distance education but also those who are shy, inhibited or reserved. In a conventional classroom 
Raviya Faritovna Stepanenko, Irina Nailjevna Ainoutdinova y Natalya Viktorovna Krotkova
246 Distance and Online Learning Solutions in the Context of Modern Legal Educational Policy

environment, the latter rarely ask questions or voice their opinions. However, communication methods of the digital environment (e.g., student chatrooms, forums, etc.) can provide these students with increased confidence and wider opportunities to be heard (Brown and Lippincott, 2003).

A well-organized digitally supported distance education may not only offer a variety of forms and modes in knowledge acquisition for many people. It may also give chance to perform improvement to students, enhance their social inclusion, form their active citizenship position, help proceed in their personal development, and raise competitiveness and employability (Shkatulla, 2007).

The results of the students `survey provided by the authors in the course of their empirical research confirmed that the majority of the "Gen Z" students clearly realize the need for higher education as a start-up for their future successful career (72\%), favor participation of teachers and instructors in their training (68\%), and admit that the delivery of university programs and courses should be organized, managed and controlled (78\%). Some students believe that a true professionalism is achievable at university if only the future specialist participates in additional educational programs or courses (54\%), purposefully take part in independent distance training courses on different open platforms as MOOCs or other open educational resources (66\%). Some students consider it necessary to bring changes into the curriculum towards increasing of hours for experiential modes of training (56\%), while others believe that only part-time work in professional environment may apply the acquired knowledge and skills for practice (43\%).

Only a small number of the respondents who have provided information for the survey do not see the need to expand education and training process to "continuity", including further regular upgrading or lifelong learning (13\%) either due to their young age or due to low motivation. The study was conducted on the grounds of Kazan University in the period from February to May, 2020. The study involved students of 2nd-4th courses of the Law Faculty. The average age of students-interviewees varied from 19 to 22 years.

\section{Summary}

The analysis of the literature on the topic proved our hypothesis that most of the trends of the 21st century teaching and learning involve various digitally supported methods, technologies, modes, forms, tools and resources. The most common trends may be presented as follows: (1) e-Learning, Web-based learning (WBL), mLearning (mobile learning), distance learning, distributed learning and other forms of online education (Warschauer, 2007); (2) Employment of real world applications - allowing 
students to apply theories to realty and see them in action (Maloy, 2016); (3) Gamification - with nearly half of the teachers admitting that they have at times incorporated online games into their classroom educational setting (Villa and Dorsey, 2017); (4) Employment of Open Source Textbooks, Massive Open Online Courses (MOOCs), crowdsourcing platforms based on networking, cooperation and collaboration, etc (Ainoutdinova et al., 2017); (5) Blended learning with its "flipped class" method, in which students first learn about a new subject at home, especially online, and then have discussions on it in the class face-to-face atmosphere - regarded as the foremost trend in education for current university students (Warschauer, 2007), etc.

It is clear that this COVID-19 pandemic has utterly disrupted all myths about education system and its gloomy perspectives. On the contrary, it has a great potential. For example, many believed that the unplanned and rapid move to online learning - with no training, insufficient bandwidth, and little preparation - will result in a poor user experience, deficiencies in peer-topeer networking or problems in teacher-to-student interaction. For those who did have access to the right technology, there was evidence that learning online could be more effective in a number of ways (Li and Lalani, 2020). Besides, clever integration of technology demonstrated higher engagement and increased motivation towards education, making some students truly "fall in love" with learning (Li and Lalani, 2020).

\section{Conclusions}

It is evident that the range of competencies of lawyers formed at university should be expanded today so as to enable them to live and work successfully in a multicultural professional environment and to effectively transform legal practice into the tasks of the evolving digital economy. The rapid development of robotics, artificial intelligence, virtual and augmented reality, etc. entails the emergence of new areas and branches of law. Widespread adoption of technology in legal practice changes the work style of lawyers, expands their access to information, and accelerates data processing, which ultimately improves ergonomics and results of their work.

This may require, depending on the topic, goals and objectives of the work, turn to technological solutions of the LegalTech service system, specially designed for professional lawyers. The system includes a variety of services, platforms, programs, products and tools created to automate the professional actions of lawyers, which, of course, is intended to facilitate, simplify and optimize many routine processes of their activities. Students most often turn to reference legal systems such as Consultant Plus and 
Raviya Faritovna Stepanenko, Irina Nailjevna Ainoutdinova y Natalya Viktorovna Krotkova
248 Distance and Online Learning Solutions in the Context of Modern Legal Educational Policy

Garant, electronic codes, judicial practice selection services for a particular case, etc. The content of most applications is normally generated with the help of artificial intelligence and contains highly accurate and reliable data. Training students to work with LegalTech services at the stage of their study at university is highly important, since these skills are extremely popular on the legal services market.

Narrower specializations within the legal profession may require, for example, training in working with Big Data, using foreign reference legal systems such as Casebook, CaseText, Jurispect, LexisNexis, Westlaw or conducting legal expertise of documents in artificial intelligence services such as eBrevia, LawGeex, Legal Robot, etc.

All these complicated tasks need special legal knowledge and ICTenhanced skills sufficient for mastering the innovative digital tools and programs. Thus, it becomes obvious that in order to meet the needs of the digital economy there shall be a review of a lawyer training methodology at university. New challenges of a digital era encourage the academic community to seek for new and relevant forms of teaching and learning, which in its turn allows intensifying and optimizing the activities. Close connection of knowledge, science and economics actualizes the request for lawyers of a "new digital formation" being relevant to the modern socioeconomic context.

\section{Acknowledgements}

The work is performed according to the Russian Government Program of Competitive Growth of Kazan Federal University.

\section{Bibliographic References}

AINOUTDINOVA, Irina; KHUZIAKHMETOV, Anvar; TREGUBOVA, Tatyana. 2017. "Advantages and disadvantages of distance education for university students in Russia" In: Modern Journal of Language Teaching Methods. Vol. 7, No. 9/2, pp. 72-86.

AINOUTDINOVA, I; BLAGOVESHCHENSKAYA, A; NURUTDINOVA, A; DMITRIEVA, E. 2019. A paradigm shift in distance education in russia towards open, massive and experiential modes of training. Available online. In: https://www.semanticscholar.org/paper/A-PARADIGMSHIFT-IN-DISTANCE-EDUCATION-IN-RUSSIA-OF-Warschauer-Kee 
gan/6681c5cb12f6402c2610cc422c16c9af27agbd21?p2df. Consultation date: $08 / 05 / 2020$.

AOKI, Kumiko. 2010. "The Use of ICT and e-Learning in Higher Education in Japan" World Academy of Science, Engineering and Technology: International Scholarly and Scientific Research \& Innovation. In: International Journal of Social, Behavioral, Educational, Economic, Business and Industrial Engineering. Vol. 4, No. 6, pp. 986-990.

BROWN, Malcolm; LIPPINCOTT, Joan. 2003. "Learning Spaces: More than Meets the Eye” In: EDUCAUSE Quarterly. Vol. 26, No. 1, pp. 14-16.

CRAWFORD, Susan. 1983. "Origin and development of a concept: the information society" In: Bulletin of the Medical Library Association. Vol. 71, No. 4, pp. 380-385.

EVANS, Chris; FAN, Jing Ping. 2002. "Lifelong learning through the virtual university" In: Campus-Wide Information Systems. Vol. 19, No. 4, pp. 127-134.

JANSEN, Cecelia; VAN DER MERWE, Petro. 2015. "Teaching Practice in the 21st Century: Emerging Trends, Challenges and Opportunities" In: Horizon Research Publishing, Universal Journal of Educational Research. Vol. 3, No. 3, pp. 190-199.

KALE, Ugur; GOH, Debbie. 2014. “Teaching style, ICT experience and teachers' attitudes toward teaching with Web 2.0" In: Education and Information Technologies. No. 19, No. 1, pp. 41-60.

KEEGAN, Desmond. 1996. Foundations of distance education (3rd ed.). Series: Routledge Studies in Distance Education. Routledge, London, UK.

KING, Frederick; YOUNG, Michael; DRIVERE-RICHMOND, Kelly; SCHRADER, Peter. 2001. "Defining Distance Learning and Distance Education. Norfolk, VA: Association for the Advancement of Computing in Education (AACE)" In: AACE Journal. Vol. 9, No. 1, pp. 1-14.

LI, Cathy; LALANI, Farah. 2020. The COVID-19 pandemic has changed education forever. Available online. In: https://www.weforum.org/ agenda/2020/04/coronavirus-education-global-covid19-online-digitallearning/. Consultation date: 01/06/2020.

INTERNATIONAL THE NEWS. 2020. SEF, Microsoft starts online classes through MS Teams \& 365 software. Available online. In: https://www. thenews.com.pk/print/696643-sef-microsoft-starts-online-classesthrough-ms-teams-365-software. Consultation date: 01/06/2020. 
Raviya Faritovna Stepanenko, Irina Nailjevna Ainoutdinova y Natalya Viktorovna Krotkova

MALOY, Robert. 2016. "Commentary: Building Web Research Strategies for Teachers and Students. Contemporary Issues in Technology and Teacher Education" In: AACE. Vol. 16, No. 2, pp. 172-183.

RAGAN, Lawrence. 2012. Principles of Effective Online Teaching: Best Practices in Distance Education. Higher Ed. Special Report / Christopher Hill (Ed.). A Magna publication: Faculty Focus. Wisconsin, USA.

SAMPSON, Nicholas. 2003. "Meeting the Needs of Distance Learners" In: Language Learning \& Technology. Vol. 7, No. 3, pp. 103-118.

SHKATULLA, Villiam. 2007. "Legal Aspects of the Modern Education System in Russia” In: Journal of Russian Law. Vol. 4, No. 124, pp. 29-39.

STEPANENKO, Ravya; LEBEDEV, Alexander; STEPANENKO, Gillva; KUZMINA, Edward. 2019. "Marginality in the socio-philosophical and juridical dimensions: The experience of an interdisciplinary approach" In: Revista San Gregorio. Vol. 34 No. Sp. Iss., pp. 6-13.

VILLA, Dana; DORSEY, Julie. 2017. The State of Gen Z 2017: Meet the Throwback Generation: White Paper. The Center for Generational Kinetics. Texas, USA.

WARSCHAUER, Mark. 2007. “The Paradoxical Future of Digital Learning” In: Learning Inquiry. Vol.1, No. 1, pp. 41-49. 
Vol.38 NEspecial

Esta revista fue editada en formato digital y publicada en diciembre de 2020, por el Fondo Editorial Serbiluz, Universidad del Zulia. Maracaibo-Venezuela 